\title{
PEMBACAAN HADIS DALAM PERSPEKTIF ANTROPOLOGI
}

\section{Muhammad Alfatih Suryadilaga}

UIN Sunan Kalijaga Yogyakarta

suryadilaga.mf@gmail.com

\begin{abstract}
The article explains, at least three important problems, related to how to read hadis through the viewpoint of anthropology as a humanical science, why do it must be solved, and then what are the implications of it, in understanding some hadis. It becomes important to be discussed because, however, Muslims' religiosity often touch humanity and social dynamic sides, constantly change and evolve. Its aim is clear, to ensure that hadis as second Muslims' life guide after the Qur'an shalih li kulli zaman wa makan. Then, by using descriptive-analysis research method and focusing on the study of hadis that explain some procedures of prayer, this can be concluded that, if we read through anthropological approach, the hadis are historical temporal valued. This means that it requires understanding and embodiment that must be adapted to the conditions of human in everytime. For example, the shape of mosque since the Prophet to present time has undergone many changes. So the forms or procedures of worship associated with that adjust for these changes, such as role of shaf in prayer, sutrah use, doing prayer on the vehicle, terrain, boats, up to recommend Muslimah to pray in jama'ah in the mosque, and so on.
\end{abstract}

Keywords: hadis, anthropology, mosque, forms or procedures of worship

\section{Abstrak}

Artikel ini menguraikan setidaknya tiga persoalan penting, terkait dengan bagaimana pembacaan hadis-hadis Nabi Saw melalui sudut pandang antropologi sebagai ilmu yang terkait dengan manusia, mengapa hal ini perlu dilakukan, kemudian seperti apa contoh implikasinya dalam pemahaman terhadap 
sebagian hadis-hadis Nabi saw. Hal ini menjadi penting untuk didiskusikan karena bagaimanapun juga keberagamaan Muslim kerap menyentuh sisi-sisi kemanusiaan serta kemasyarakatan yang dinamis, senantiasa berubah dan berkembang. Fungsinya adalah supaya hadis sebagai pedoman kedua umat Muslim setelah alQur'an menjadi shalih li kulli zaman wa makan. Kemudian dengan menggunakan metode deskriptif analitis, serta memfokuskan pada penelitian terhadap hadis-hadis yang menerangkan tentang beberapa tatacara pelaksanaan shalat, memberikan simpulan bahwa jikalau dibaca dengan pendekatan antropologi, maka hadishadis tersebut bersifat historis temporal. Artinya membutuhkan pemahaman dan pengejawantahan yang mesti disesuaikan dengan kondisi umat manusia di setiap zaman. Contohnya adalah bentuk bangunan masjid yang sejak masa Nabi sampai sekarang telah banyak sekali mengalami perubahan. Sehingga berarti tatanan peribadatan yang terkait dengannya pun menyesuaikan bentuk perubahan tersebut, seperti barisan jamaah atau shaf, penggunaan sutrah, pelaksanaan shalat di atas kendaraan, tanah lapang, perahu, hingga dianjurkannya Muslimah untuk berjamaah di masjid dan sebagainya.

Kata Kunci: hadis, antropologi, masjid, tata cara beribadah

\section{A. Pendahuluan}

Kajian tentang Islam dengan menggunakan antropologi kini telah banyak bermunculan antara lain Fadwa el-Guindi Modesty, Privacy and Resistance telah diterjemahkan ke bahasa Indonesia dengan judul Jilbab antara Kesalehan, Kesopanan dan Perlawanan. ${ }^{1}$ Hal baru dalam kajian dalam buku tersebut adalah melalui pendekatan antropologi. Kesimpulan yang menarik adalah jilbab bukan hanya pakaian muslim belaka, bukan monopoli Islam dan bukan berasal dari Arab. ${ }^{2}$ Kajian lain akan pentingnya antropologi dalam studi Islam juga dikemukakan oleh Amin Abdullah. ${ }^{3}$ 
Kajian tentang antropologi di atas akan menarik manakala dilakukan kajian pada Hadis. Selama ini, pergulatan ummat Islam atas sumber ajaran Islam kedua (hadis) sangat beragam. Perdebatan panjang yang sudah ada adalah kemunculan aliran ahl al-hadisis dan ahl ar-ra' yi. ${ }^{5}$ Itulah pola yang dikenal oleh ummat Islam dalam merespons teks keagamaan yang sifatnya normatif. Artinya, perkembangan kondisi masyarakat tidak sebanding dengan produk teks. Di sisi lain, berkembangnya dinamika kemasyarakatan menuntut ummat Islam senantiasa dapat mempertahankan keberagamaan-nya. Waktu berjalan terus menerus sehingga problem masyarakat dan pola tatanan di dalamnya berbeda termasuk di dalamnya yang terkait erat dengan kebudayaan.

Problem di atas, juga melanda atas hadis Nabi saw. terutama yang terkait erat dengan kajian antropologi. Sebagaimana diketahui bahwa ilmu antropologi menjelaskan perbedaan dan persamaan antara kebudayaan manusia yang tersebar di segala penjuru dunia, mencari jawaban atas perubahan kebudayaan manusia, menjelaskan fenomena sosial budaya yang terjadi dalam kehidupan manusia dan menjelaskan perilaku manusia. Semuanya adalah pertanyaan dasar dari Antropologi yang harus dicari jawabannya melalui penelitian ilmiah. ${ }^{6}$

Perspektif antropologi di atas adalah antropologi terhadap gejala sosial budaya. Dalam Antropologi ada tiga macam perspektif besar di dalam melihat gejala sosial budaya yakni: perspektif yang menekankan pada analisis masyarakat dan kebudayaan, perspektif yang menekankan faktor waktu, yang terdiri dari proses historis dari masa lampau sampai masa kini (diakronik), masa kini (sinkronik), dan interaksi masa lampau dan masa kini (interaksionis) dan perspektif konstelasi teori-teori, yakni penggabungan kedua perspektif. $^{7}$

Bentuk bangunan masjid pada masa kenabian sangat berpengaruh dengan pesan yang disampaikan Nabi saw. Masjid yang sering dilihat di masa sekarang, pada masa lampau tidak demikian. Kenyataan ini bisa diperkuat dengan adanya pesan yang disampaikan Nabi saw. seperti dalam hal musim hujan, maka mu'ażżin sering menyampaikan pesan agar shalat di rumah. ${ }^{8}$ Demikian pula tentang perlunya menggunakan sutrah (penghalang) dalam shalat. ${ }^{9}$ Atau persoalan lain seperti saf shalat, batalnya shalat dan sebagainya. 
Berdasar uraian tersebut, secara singkat artikel ini hendak menjawab tiga persoalan pokok. Pertama adalah terkait dengan bagaimana pembacaan hadis-hadis Nabi Saw melalui sudut pandang antropologi sebagai ilmu yang terkait dengan manusia. Kedua, mengapa upaya ini menjadi perlu untuk dipecahkan. Kemudian ketiga, seperti apa contoh implikasinya dalam pemahaman terhadap sebagian hadis-hadis Nabi saw. Demi mengoptimalkam pemahaman, maka kajian ini hanya akan memfokuskan pada persoalan seputar perintah shalat dan hal-hal lain yang melingkupinya yang dikaji. Adapun metode yang digunakan dalam kajian ini adalah deskriptif analitik yang bertujuan pokok untuk menerangkan dan mengungkapkan beberapa hadis terkait serta melakukan interpretasi kritis terhadapnya melalui pendekatan antropologi. Kajian ini menjadi penting untuk didiskusikan mengingat banyaknya jumlah hadis yang berkaitan dengan sisi-sisi kemanusiaan, namun dalam aplikasinya tidak banyak yang mempertimbangkan latar tersebut sebagai alternatif dalam upaya memahami hadis secara lebih komprehensif sehingga relatif lebih applicable dan responsif terhadap perkembangan zaman.

\section{B. Tinjauan Pustaka}

Pembacaan hadis dengan pendekatan ilmu-ilmu sosial bukanlah merupakan hal baru. Beberapa ilmuan Muslim modern kontemporer telah memulai gagasan serupa. Fazlurrahman merupakan diantara penggagas wacana sunnah-sunnah yang hidup. Rahman menyebut bahwa Living sunnah biasanya dihadapkan dengan istilah prophetic sunnah yang berarti 'warisan ideal dari aktivitas kenabian', sementara living sunnah adalah sunnah kenabian (prophetic sunnah) yang dielaborasi dan diinterpretasi secara kreatif ketika menemukan perubahan-perubahan, tantangantantangan dan kondisi-kondisi baru yang dihadapi oleh komunitas muslim. ${ }^{10}$

Senada dengan Rahman, Fatimah Mernissi merupakan salah seorang feminis yang kental menyerukan wacana hermeneutika hadis. Adapun yang menjadi pokok pemikiran Fatima Mernissi adalah bahwa ia berusaha melakukan kajian-kajian terhadap teksteks keagamaan, khususnya hadis, yang di dalamnya terdapat sikap antipati terhadap perempuan (misoginis). Fatima Mernissi 
melakukan penelitian ganda-secara historis dan metodologismengenai hadis-hadis tersebut beserta para perawinya, terutama dalam kondisi bagaimana hadis tersebut pertama kali diucapkan, siapa yang mengucapkannya, di mana, kapan, mengapa, dan kepada siapa hadis itu ditujukan. ${ }^{11}$

Muhibbin dalam tesisnya yang berjudul Hadis dalam Perspektif Kontemporer: Kajian Kritis terhadap Hadis-Hadis Politik mengemukakan urgensi memahami hadis-hadis bernuansa politik secara lebih komprehensif. Upaya untuk membaca hadishadis secara kontekstual dengan pendekatan politik modern menjadi niscaya sehingga mampu teraplikasikan secara proporsional. $^{12}$ Muh. Tasrif juga telah menguraikan dalam beberapa bagian tesisnya yang berjudul Pemikiran Hadis di Indonesia: Wacana tentang Kedudukan dan Pemahaman terhadapnya terkait dengan bagaimana memahami hadis Nabi saw. menggunakan pendekatan sosial-historis. ${ }^{13}$

Abdul Mustaqim dalam artikelnya yang berjudul Paradigma Interkoneksi dalam Memahami Hadis Nabi (Pendekatan Historis, Sosiologis, dan Antropologis) mengemukakan perlunya memahami hadis melalui pendekatan historis, sosiologis, dan antropologis demi mendapatkan pemahaman hadis yang relatif lebih akomodatif, dinamis, dan apresiatif terhadap perkembangan zaman. ${ }^{14}$ Seirama dengan itu adalah artikel Suryadi yang berjudul Rekonstruksi Metodologis Pemahaman Hadis Nabi yang mengusulkan kajian hermeneutik sebagai salah satu metode alternatif dalam memahami hadis Nabi saw. untuk bisa melahirkan pemahaman hadis Nabi yang acceptable dan puncaknya menjadi hudan li an-nās. ${ }^{15}$

\section{Pembacaan Hadis Perspektif Antropologi}

Banyaknya mazhab dalam hukum Islam dan kitab-kitab yang bernuansakan fiqih menjadikan kajian yang berkembang di masyarakat cenderung ke arah fiqih oriented. Pembacaan yang selama ini berkembang adalah terkait erat dengan hukum. ${ }^{16}$ Seperti seputar persoalan shalat yang sangat terkait erat dengan bangunan masjid, seperti shalat jamaah, shalat memakai sandal, sepatu, shaf, dan lain-lain. Sebagaimana digambarkan dalam hadis berikut: 


\begin{tabular}{|c|c|c|}
\hline No. & Hadis & Tema \\
\hline 1 & 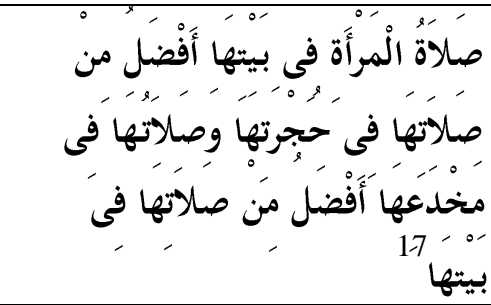 & $\begin{array}{l}\text { Sebaik-baik masjid bagi } \\
\text { perempuan adalah kamar } \\
\text { rumah-rumah mereka }\end{array}$ \\
\hline 2 & وخيرصفوف الرجال أولهاوشرهاأخرها، & $\begin{array}{l}\text { Sebaik-baik shaf shalat laki- } \\
\text { laki adalah terdepan dan } \\
\text { sebaliknya perempuan yang } \\
\text { paling akhir }\end{array}$ \\
\hline 3 & 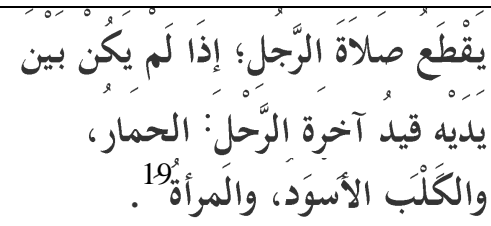 & $\begin{array}{l}\text { Shalat terputus karena } \\
\text { himar, anjing hitam dan } \\
\text { perempuan }\end{array}$ \\
\hline 4 & 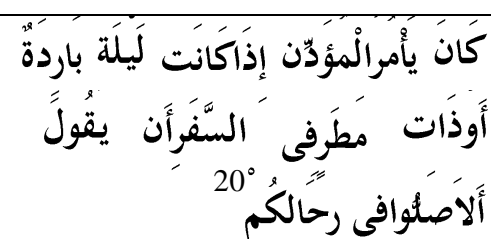 & $\begin{array}{l}\text { Perintah kepada Muazzin } \\
\text { untuk shalat berjamaah di } \\
\text { kendaraan atau di rumah }\end{array}$ \\
\hline 5 & 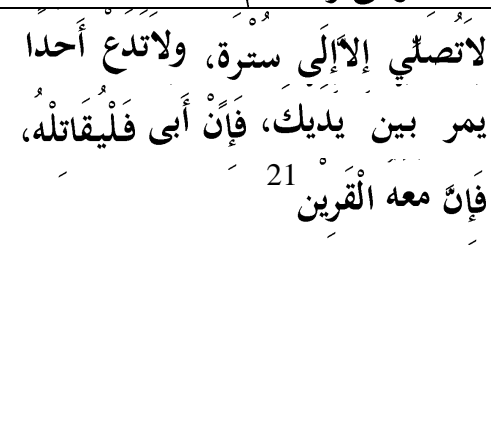 & $\begin{array}{l}\text { janganlah kalian shalat, } \\
\text { kecuali menghadap sutrah } \\
\text { dan janganlah kalian } \\
\text { membiarkan seorang pun } \\
\text { lewat di hadapanmu, jika dia } \\
\text { menolak hendaklah kamu } \\
\text { bunuh dia, karena } \\
\text { sesungguhnya ada syetan } \\
\text { yang bersamanya }\end{array}$ \\
\hline 6 & 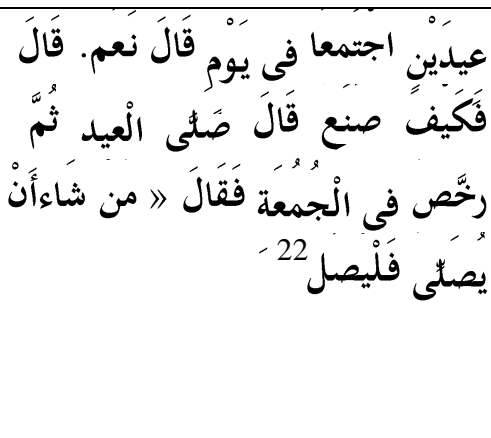 & $\begin{array}{l}\text { Apakah kamu pernah } \\
\text { bersama Rasulullah saw. } \\
\text { terjadi dua id terkumpul } \\
\text { dalam satu hari?", ia } \\
\text { menjawab: "Iya (pernah)", } \\
\text { Mu'awiyah bertanya: } \\
\text { "Bagaimanakah yang beliau } \\
\text { lakukan", ia menjawab: } \\
\text { "Beliau saw. shalat 'ied }\end{array}$ \\
\hline
\end{tabular}




\begin{tabular}{|c|c|c|}
\hline & & $\begin{array}{l}\text { kemudian memberikan } \\
\text { keringanan untuk shalat } \\
\text { Jum'at, beliau bersabda: } \\
\text { "Barangsiapa yang hendak } \\
\text { shalat maka shalatlah ia" }\end{array}$ \\
\hline 7 & 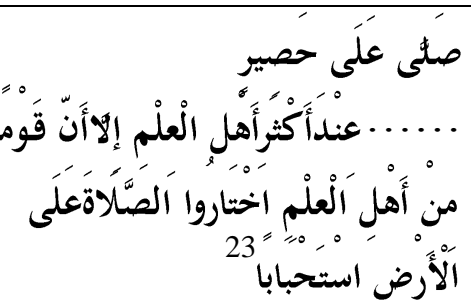 & $\begin{array}{l}\text { Shalat di atas tikar atau } \\
\text { bumi }\end{array}$ \\
\hline 8 & والأرض كلها مسجد إلالمقبرة 24 & $\begin{array}{l}\text { Seluruh bumi adalah masjid } \\
\text { kecuali kuburan dan kamar } \\
\text { mandi }\end{array}$ \\
\hline
\end{tabular}

Berbagai persoalan di atas, tidak semuanya berdimensikan sesuatu yang profan atau maḥ̣h. Namun, kebanyakan ahli syarah hadis dan ulama memahamai hadis-hadis di atas dalam konteks hukum atau fiqih.

Persoalan pemahaman hadis di atas, akan lebih bijaksana manakala dilihat dalam konteks fungsi Rasulullah saw. apakah kapasitas hadis yang terkait ibadah shoalat itu terkait fungsi kenabian atau fungsi lain yang sifatnya historis. Dalam hal ini, jika sifatnya umum atau universal yang terkait shalat, maka hukumnya tetap ( $\dot{s} a w a \bar{a}$ it) dan tidak ada yang boleh mengganggu gugat sampai kapanpun, siapapun dan di manapun, seperti waktu pelaksanaan ibadah shalat atau formulasi gerakan dan doa di dalam shalat. Adapun hal-hal yang terkait erat dengan hadis di atas lebih banyak bernuansakan historis atau lokal yang sifatnya bisa berubah (mutagayyirāt).

Untuk membedakan sebuah hadis apakah merupakan suatu yang harus dilaksanakan sepanjang masa, seperti al-Qur'an yang dikenal dengan șālih likulli zamān wa makān, maka perlu dilihat apakah hadis tersebut berdimensikan umum/universal ataukah berdimensikan lokal/terbatas. Sabda kenabian atau risalah kenabian yang universal biasanya berlaku sepanjang masa, misalnya penegakan rukun Islam, Iman dan akhlak. Sementara hal-hal lain sebagaimana tergambar dalam hadis di atas, tidak berkenaan 
dengan esensi ibadah. Persoalan sutrah, penghalang ketika shalat di sebuah area yang tidak menandakan sebagai sebuah tempat ibadah. Persoalan ini akan selesai, manakala sudah ada bangunan spesifik untuk shalat. Namun, sebagaian masyarakat ada yang masih menggunakan sutrah walaupun ketika shalat di masjid.

Kajian di atas, tentu tidak akan menarik lagi, jika hanya dibumbui oleh kajian yang klasik dan berkembang pada abad ke-7 sebagaimana dalam kitab syarah hadis. Tentunya, dalam kitab syarah hadis, persoalan-persoalan kajian dalam hadis sebagaimana dalam tabel di atas akan lebih banyak dikaji berdasarkan hukum semata.

Pola pemahaman hadis di atas jika menganggap sebagai sesuatu yang tetap dan tidak berubah, maka seharusnya tetap dilaksanakan sampai kapanpun. Namun, dalam kaidah fiqih atau ushul fiqih juga ditemukan adanya kaidah الوسائل لها أحكام المقاصد menunjukkan bahwa sarana tunduk kepada tujuan (maqāṣid). Sarana dan prasana yang terkait erat dengan ibadah shalat telah berubah dan berkembang pesat. Pada awal Islam, ketika bangunan Masjid atau tempat shalat yang spesifik belum banyak dibangun, maka Nabi Muhammad saw. memberikan kelonggaran bahwa setiap bumi Allah swt. adalah masjid dan bisa dijadikan untuk shalat. Seperti gambar di bawah ini:

Gambar 1. Pelaksanaan Ibadah Sholat

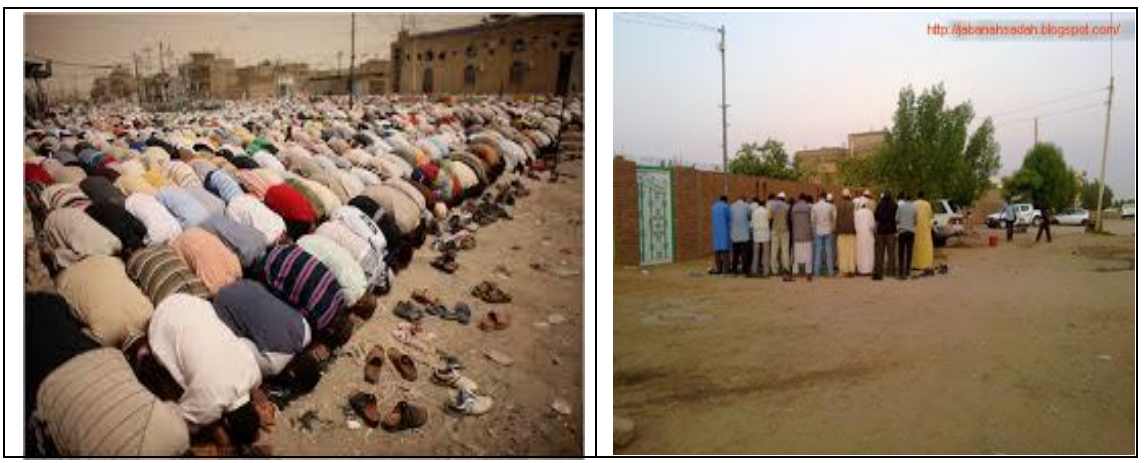




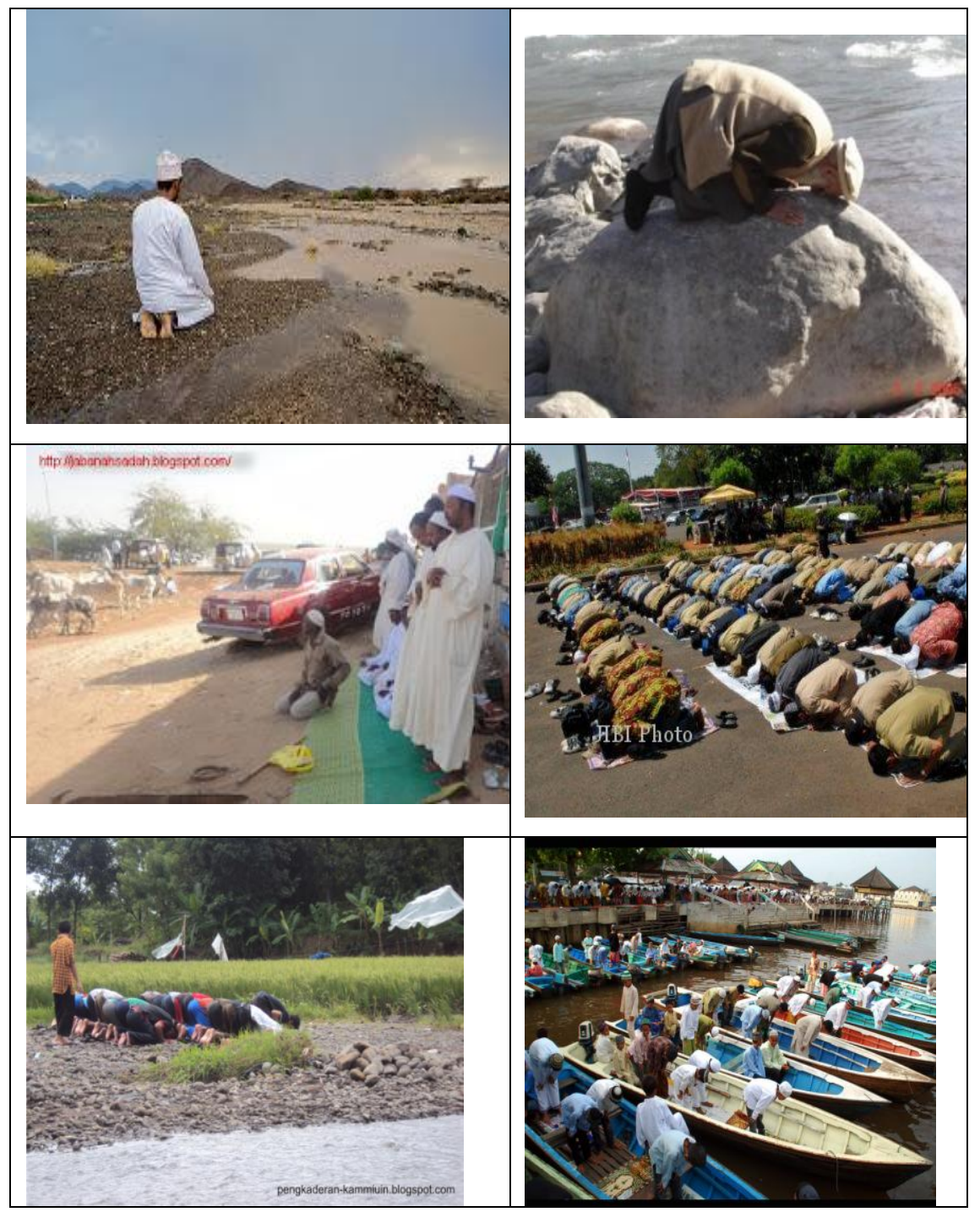

Gambar di atas menunjukkan bahwa, seperti apapun kewajiban shalat tetap harus dilakukan jika waktu shalat telah masuk. Di manapun ummat Islam berada tetap harus menjalankan shalat. Tradisi di atas banyak terjadi di Timur Tengah yaitu ketika shalat di tanah lapang, sebaliknya shalat di perahu tidak mungkin ada di zaman nabi, Hijaz (Makkah dan Madinah). Namun berbeda dengan di Indonesia, banyak masjid dibangun di lingkungan masyarakat dan perkantoran. Bahkan, sekarang jarang ditemukan ummat Islam Indonesia shalat di tempat luas seperti gambar di atas. 
Ummat Islam sekarang lebih banyak yang shalat di Masjid atau di kantor atau dirumah.

Suatu hal lain, gambaran kaum muslim shalat sebagaimana di atas memungkinkan untuk shalat dengan memakai sandal/sepatu, sebagai tergambar di bawah ini:

Gambar 2. Pola Beribadah dalam Sholat

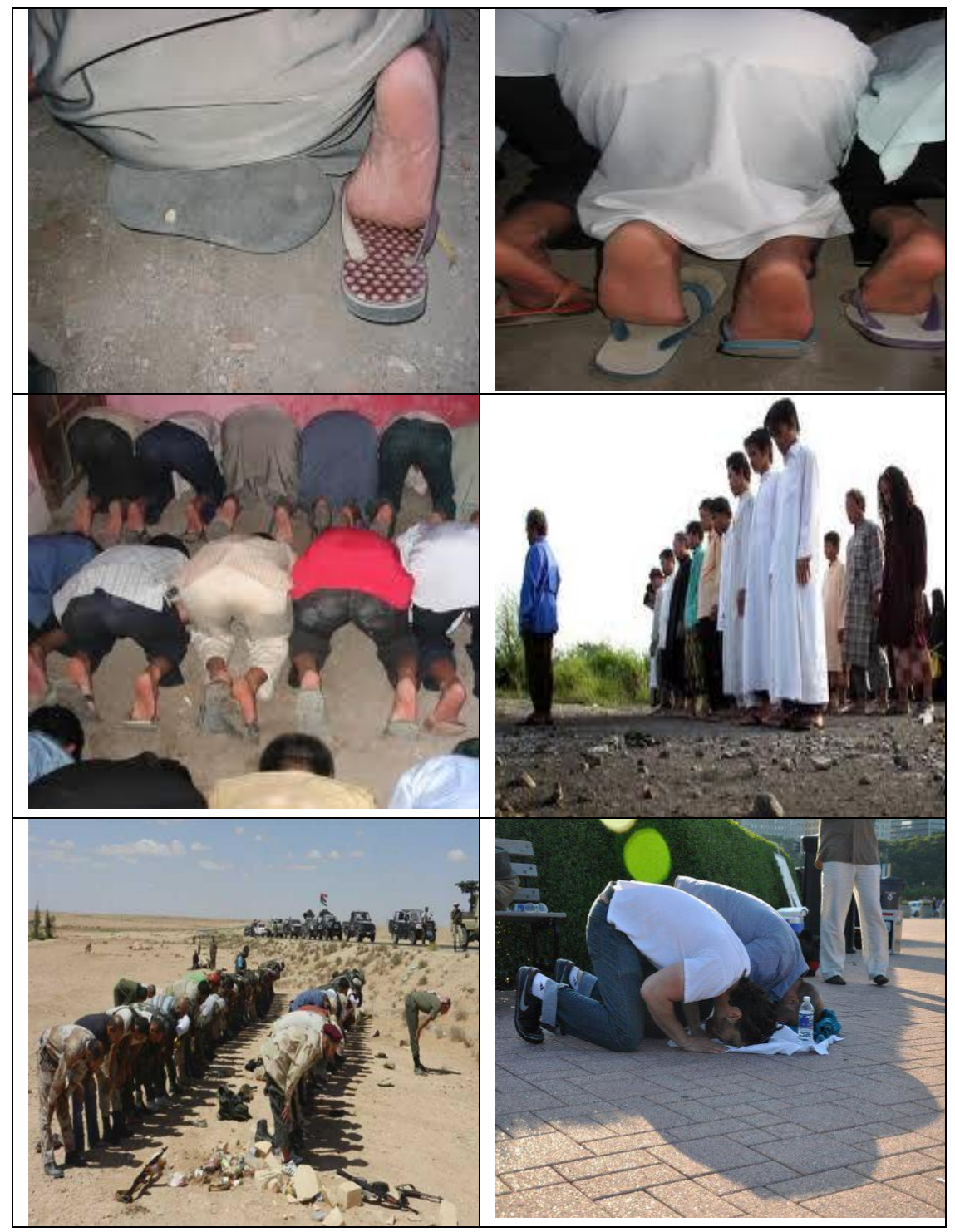


Berbeda dengan apa yang terjadi sekarang, dengan adanya bentuk bangunan masjid yang permanen dan dibuat bersih, rapi dan suci dari segala najis, maka shalat dengan memakai sandal tidak dimungkinkan lagi. Hal ini dikarenakan untuk menjaga kebersihan dan kesucian masjid. Pengecualian akan bisa dimaklumi bagi mereka yang sakit kalau kena dingin bisa menimbulkan penyakit yang parah, maka memakai sandal dalam shalat tetap dibolehkan. Tentunya, sandal atau sepatu yang dipakai adalah yang tidak digunakan di luar area masjid (khusus dipakai di dalam).

Jika melihat evolusi interaksi ummat Islam atas bangunan masjid dapat dilihat sebagaimana dalam gambar di bawah ini, di mana masjidil haram sebagai rumah ibadah pertama di bumi ini juga mengalami perkembangan. Begitu pula dengan masjid-masjid lainnya di seluruh penjuru dunia ini.

Gambar 3. Sholat di Masjidil Haram dan Masjid Lainnya

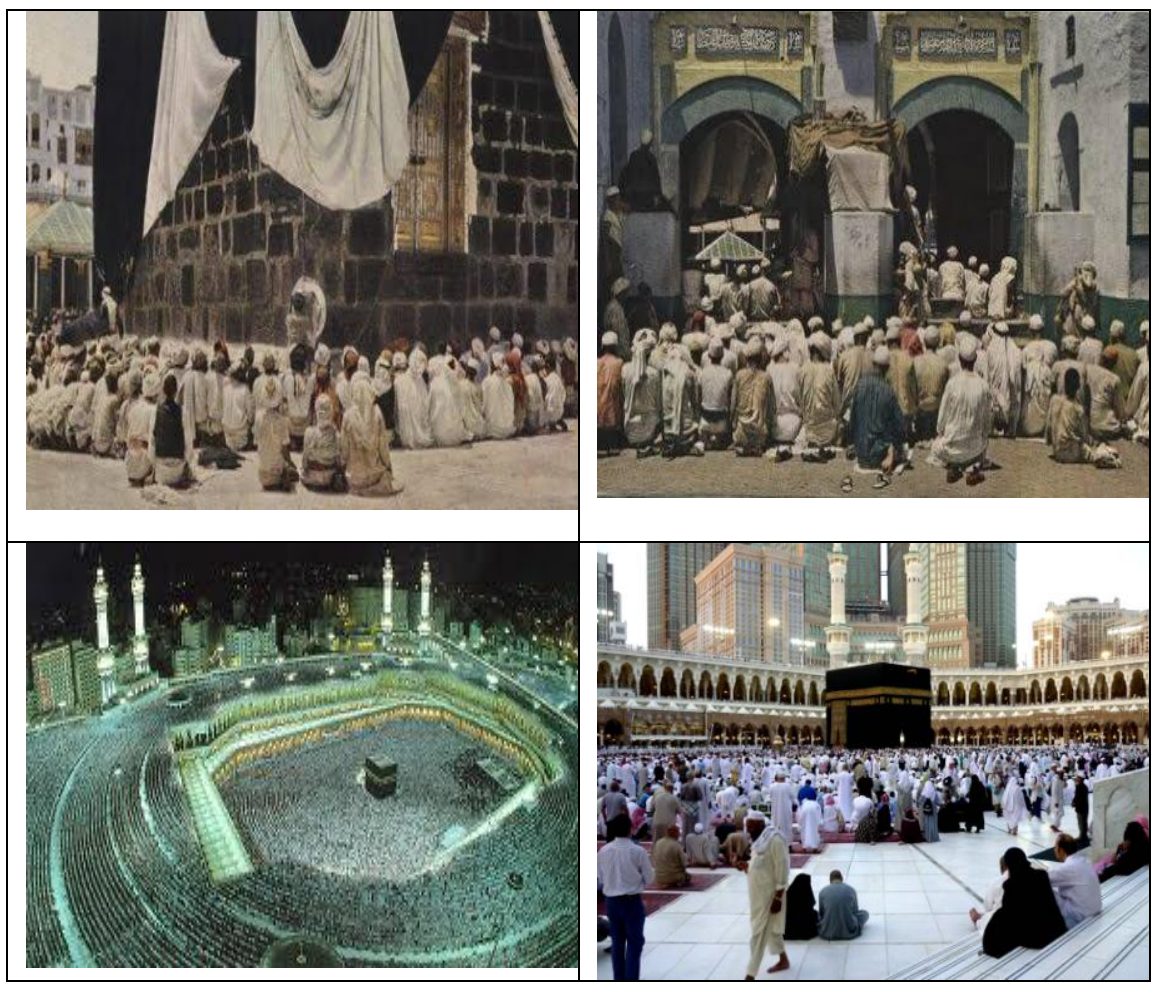




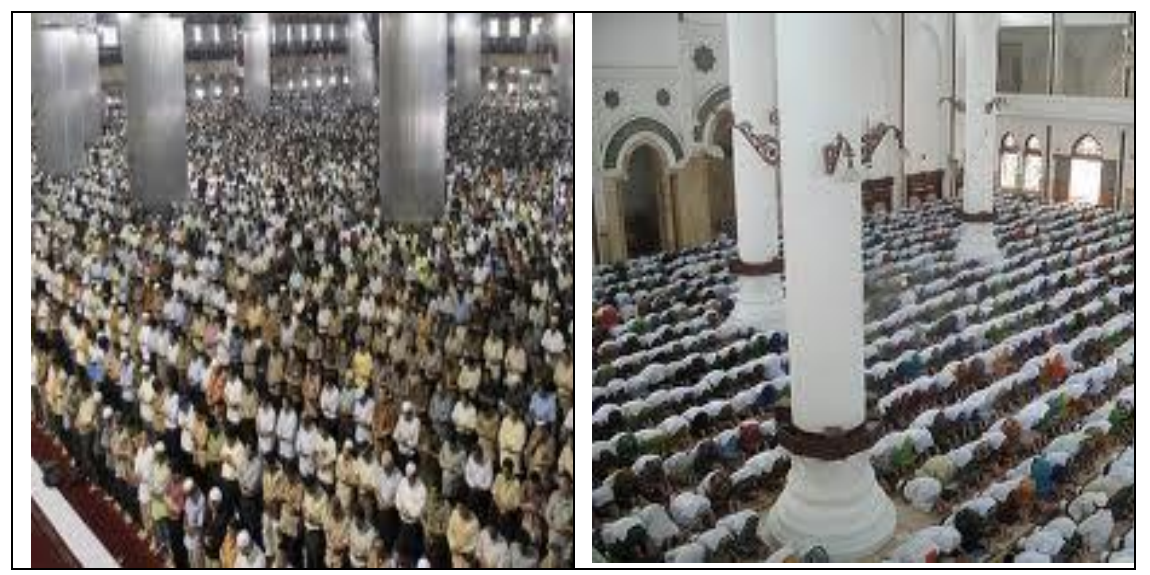

\section{Berubahnya Tempat Shalat Berubah Pula Tatanan yang Terkait di dalamnya}

Masjid merupakan rumah tempat ibadah umat Muslim. Masjid artinya tempat sujud, dan mesjid berukuran kecil juga disebut musholla, langgar atau surau. Selain tempat ibadah masjid juga merupakan pusat kehidupan komunitas muslim. Kegiatankegiatan perayaan hari besar, diskusi, kajian agama, ceramah dan belajar al-Qur'an sering dilaksanakan di Masjid. ${ }^{27}$ Bahkan dalam sejarah Islam, masjid turut memegang peranan dalam aktivitas sosial kemasyarakatan hingga kemiliteran. ${ }^{28}$

Masjid, merupakan suatu karya budaya yang hidup, karena ia merupakan karya arsitektur yang selalu diciptakan, dipakai oleh masyarakat muslim secara luas, dan digunakan terus-menerus dari generasi ke generasi. Tiap daerah tertentu memiliki keistimewaan dan karakteristik sendiri dalam bangunannya. Karena itu, sebagai bangunan relijius, masjid adalah representasi dari komunitas ummat Islam yang melahirkan dan memakmurkannya.

Gambar 4. Masjid tempat Melaksanakan Sholat

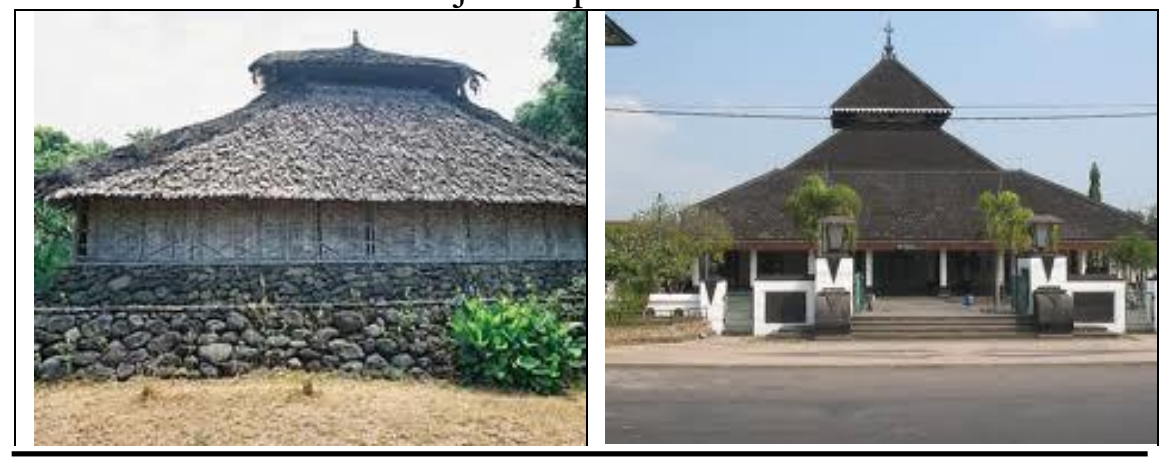




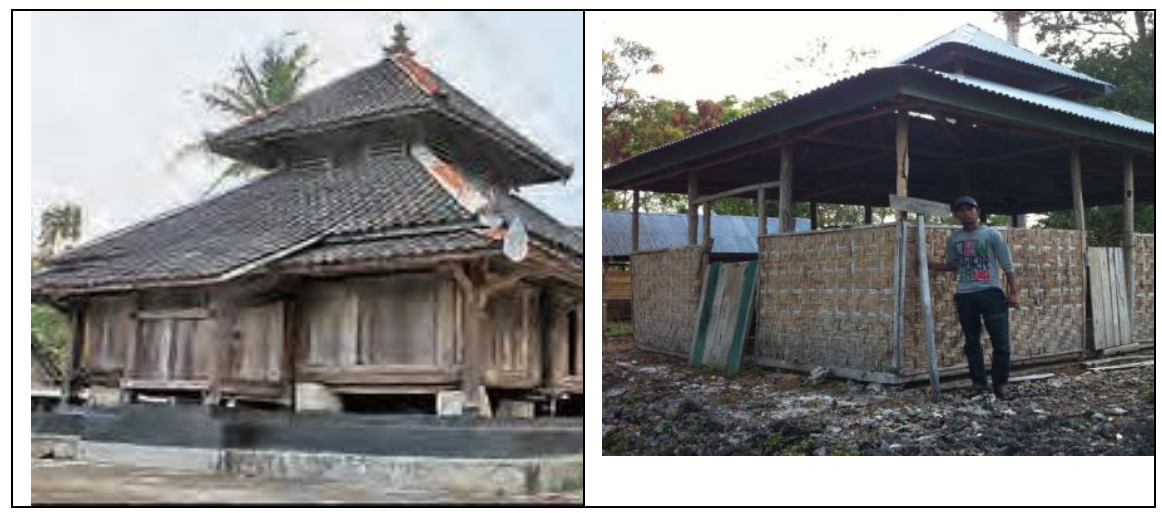

Jauh sebelum Islam berkembang menjadi agama besar pada zaman Nabi Muhammad SAW, telah lahir para nabi dan rasul yang mendahuluinya. Pada periode ini pula telah dibangun sebuah masjid pertama kali di dunia. Yaitu Masjid al-Haram pada zaman Nabi Ibrahim as. Namun, masjid pada masa itu tidak seperti bangunan sekarang yang lengkap dengan menara dan bangunan megah lengkap dengan tiang-tiang besar. Masjid pada waktu itu hanya berupa tempat lapang dengan batas-batas tertentu yang digunakan untuk beribadah dan bermunajat kepada Allah.

Sebagaimana diketahui sebelumnya, adanya pelarangan perempuan shalat di masjid dan memakai minyak wangi merupakan konsekwensi dari bentuk tatanan masjid pada masa tersebut. Sebagaimana diketahui pula dengan bentuk seperti lapangan yang luas dan sangat memungkinkan sekali banyaknya orang yang lalu lalang. Kondisi seperti itulah yang menjadikan perempuan lebih aman untuk beribadah di rumah masing-masing ketimbang di masjid. Apalagi perempuan yang memakai minyak wangi karena dapat menyebabkan hal-hal yang tidak diinginkan.

Kenyataan senada juga berlaku ketika musim hujan. Nabi saw. selalu memerintahkan bilal untuk menambahkan kata-kata tertentu $^{29}$ yang isinya agar shalat di rumah masing-masing. Demikian pula ketika pada hari raya (baik idhul fitri maupun idul adha) yang jatuh pada hari Jum'at. Hadis Nabi saw. memberikan rukhşah atau keringanan untuk tidak shalat Jum'at di masjid melainkan cukup melakukan shalat dhuhur saja. ${ }^{30}$ Hal ini dikarenakan, jika ummat Islam diwajibkan ke masjid maka sangat melelahkan padahal paginya sudah berkumpul shalat Id di masjid, sedangkan lokasi tempat tinggal para shahabat pada waktu itu tidak 
hanya berada dalam satu wilayah, di Madinah, saja. Berbeda dengan masa sekarang yang sangat mudah dalam menemukan masjid.

\section{E. Tempat Shalat yang Ramah Perempuan}

Sebagaimana telah sedikit disinggung di atas, bahwa adanya perdebatan tetang boleh tidaknya perempuan untuk shalat di masjid merupakan konsekwensi dari bentuk bangunan masjid pada masa Nabi. Jika menelusuri sejarah tempat shalat berjamaah di zaman nabi merupakan tempat yang terbuka. Bangunan masjid pada masa itu belumlah seperti bangunan masjid pada era sekarang yang dikelilingi tembok, atap, lantai yang bersih dan nyaman. Bangunan masjid pada masa nabi merupakan tempat yang terbuka. Sehingga sangat memungkinkan orang-orang umum melihatnya. Pada masa itu shalat jamaah dilakukan ditempat yang luas, seperti lapangan dan hanyalah diberi batas seperti batu agar ketika shalat tidak ada yang lewat di depannya.

Keberadaan Masjidil Haram pada saat itu yang sangat penting bagi umat Islam karena terdapat Ka'bah di tengahtengahnya, belumlah dapat digunakan sepenuhnya oleh Nabi dan kaum muslim-muslimat. Sebab pada saat itu Masjidil Haram dengan Ka'bah di dalamnya juga digunakan sebagai tempat ritual oleh penganut agama lain. Sehingga pada saat itu, wujud kebudayaan fisik, seperti tempat ibadah, belumlah mendapat perhatian khusus. Hal itupun terjadi di luar Masjidil Haram. Pada masa itu shlat berjamah masih dilakukan di tempat-tempat yang lapang, tanpa dinding dan atap. Sehingga sangat memungkinkan sekali ketika shalat banyak orang yang berlalu lalang.

Keadaan masjid pada saat itu tentu akan memepengaruhi sebuah etika atau norma-norma dalam shalat, termasuk bagi perempuan. Tempat yang lapang tanpa atap dan dinding serta banyaknya orang yang berlalu lalang tentu tidak aman bagi perempuan. Karena akan mengundang banyak perhatian publik. Oleh sebab itulah, perempuan pada saat itu lebih diutamakan untuk melaksanakan shalat di rumah. Namun pemahaman ini sampai sekarang belum banyak berubah. Padahal kondisi sosoial dari sejak saman nabi sampai sekarang telah banyak mengalami perubahan.

Bangunan masjid pada masa Nabi sampai sekarang telah banyak sekali mengalami perubahan. Dulu shalat berjamaah 
dilakukan ditempat yang lapang dan terbuka, tanpa atap dan dinding, namun sekarang bangunan masjid telah berkembang dengan berbagai bentuknya yang semakin modern. Perubahan budaya dan kondisi sosial semacam ini hendaknya bisa merubah pemaham baru terhdap hadis nabi. Terutama yang berkaitan dengan perempaun, yaitu tentang boleh dan tidaknya perempuan melakukan shalat berjamaah di masjid. Jika dulu pertimbangannya adalah keamaan dan kenyamaan, maka seharunya zaman sekarang dengan melihat bangunan masijid yang ramah perempaun menjadikan perempuan boleh dan mudah untuk melakukan shalat berjamaah di masjid.

Pada era sekarang banyak dijumpai bangunan masjid yang ramah terhadap perempun. Bahkan, banyak bangunan masjid di era sekarang memberikan tempat khusus bagi kaum perempuan agar nyaman melakukan ibadah di dalam masjid. Mulai dari jalan khusus perempuan yang tidak boleh bercampur dengan laki-laki, tempat wudhu khusus perempuan, kamar ganti khusus perempuan dan tempat shalat khusus perempuan yang semuanya tertutup dari pandangan laki-laki. Sehingga kaum perempuan bisa nyaman melakukan ibdah di dalam masjid.

Perintah bagi kaum perempuan pada masa Nabi untuk lebih baik menjalankan shalat di rumah tentu ada alasannya, yaitu demi keamanan dan kenyamanan dengan mempertibangkan bangunan masjid pada masa itu yang belum ramah terhadap kaum perempaun. Namun demikian, sebenarnya banyak hadis nabi yang tidak melarang kaum perempuan untuk melakukan shalat berjamaah bersama Rasul.

Rasululullah saw. bersabda;
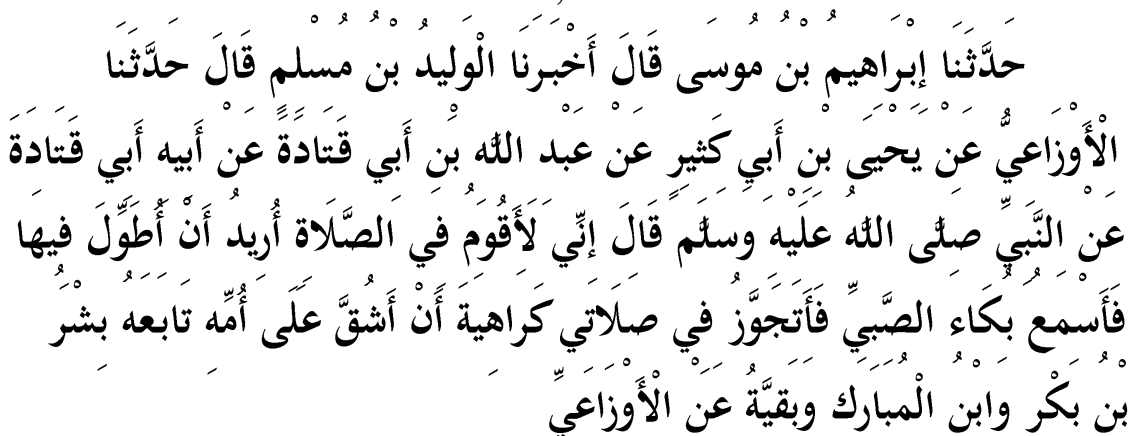

Telah menceritakan kepadă kami Ibrāhìm bin Mūsà bérkata, telah mengabarkan kepada kami Al Wālid bin Muslim berkata, telah menceritakan kepada kami Al Auzā'i dari Yahya bin Abū 


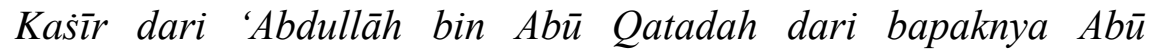
Qatadah dari Nabi SAW, beliau bersabda: "Aku pernah ingin memanjangkan salat, namun aku mendengar tangisan bayi. Maka aku pendekkan shalatku karena khawatir akan memberatkan ibunya." Hadis ini dikuatkan oleh Bisyr bin Bakar dan Ibnu Al Mubarak dan Baqiyyah dari A-Auzā'i. ${ }^{3}$

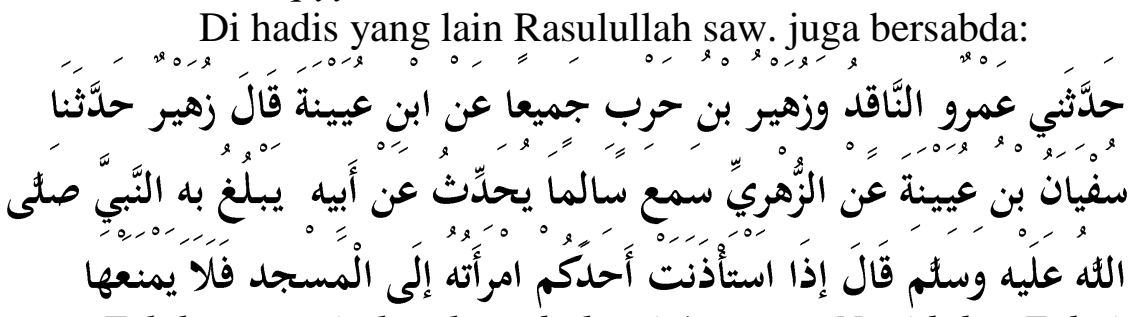

Telah menceritakan kepada kami Amru an=Naqid dan Zuhair bin Harb semuanya meriwayatkan dari Ibnu 'Uyainah, Zuhair berkata, telah menceritakan kepada kami Sufyan bin 'Uyainah dari az-Zuhri dia mendengar Sālim bercerita dari Bapaknya yang merafa'kan kepada Nabi SAW, beliau bersabda, "Apabila istri salah seorang dari kalian meminta izin kepada kalian ke masjid maka janganlah dia melarangnya'.,132

Hadis di atas menjelaskan bahwa tidak ada larangan bagi kaaum perempaun untuk mengikuti shalat berjamaah di masjid, selama tempat dan keadaannya memungkin. Selain mepertimbangkan tempat yang ramah, aman dan nyaman, kaum perempuan juga harus memperhatikan norma-normanya, seperti tidak boleh memakai wangi-wangian, pakaian mencolok yang dapat mengundang perhatian orang lain juga menjaga akhlakakhlak sebagaimana mestinya.

Rasulullah bersabda:

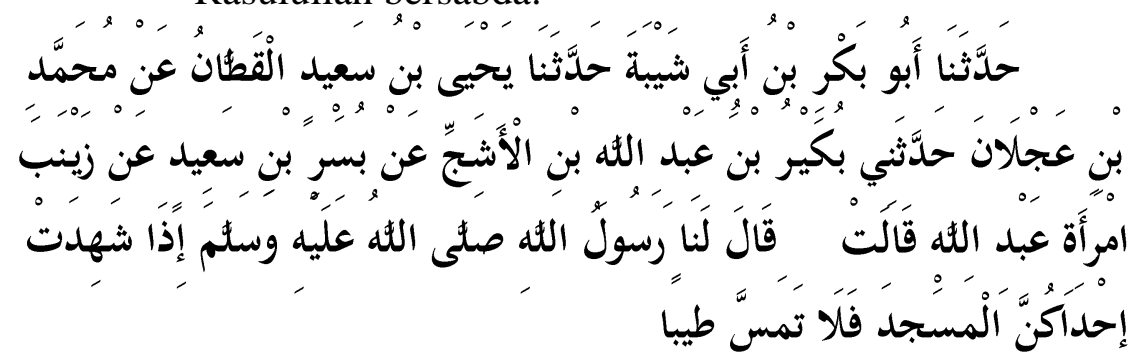

Telah menceritakan kepada kami Abū Bakar bin Abī Syaibah telah menceritakan kepada kami Yahya bin Sa'̄̃d al-Qattan dari Muhammad bin 'Ajlān telah menceritakan kepadaku Bukair bin 
'Abdullāh bin al-Asyajj dari Busr bin Sa'̄̄d dari Zainab, istri Abdullāh dia berkata, "Rasulullah saw. bersabda kepada kami, 'Apabila salah seorang dari kalian kaum wanita hendak menghadiri shalat di masjid maka janganlah kalian memakai wangi-wangian'."133

Hadis-hadis di atas jelas tidak melarang kaum perempaun untuk ikut serta shalat berjamaah di masjid. Tentu dengan mempertimbangkan bangunan masjid yang sudah ramah perempuan juga kaum perempaun tetap memelihara kehormatannya. Tempat dan bangunan masjid yang ramah perempuan tentu menjadikan kaum perempuan aman pada șaff (barisan) shalat di belakang, namun juga bisa di atas (lantai dua) atau sejajar dengan jamaah laki-laki, selama bangunan masjid tersebut memungkinkan, dalam arti bangunan yang melindungi dan ramah terhadap kaum perempuan.

\section{F. Simpulan}

Berdasarkan pembahasan tersebut, dapat disimpulkan bahwa hadis-hadis yang menerangkan tentang beberapa tatacara pelaksanaan shalat sebagaimana dikemukakan di atas, jikalau dibaca melalui sudut pandang antropologi, ia bersifat historis temporal. Artinya membutuhkan pemahaman dan pengejawantahan yang mesti disesuaikan dengan kondisi umat manusia di setiap zaman, tentu dengan satu maksud menomorsatukan ruh atau spirit dari ibadah tersebut. Hal ini karena sejak masa wurudnya wahyu hadis hingga sekarang terdapat berbagai perubahan dan atau perkembangan situasi dan kondisi yang terjadi. Contohnya adalah wujud bangunan masjid yang pada masa Nabi sampai sekarang telah banyak sekali mengalami perubahan, sehingga berarti tatanan peribadatan pun berubah menyesuaikan bentuk perubahan tersebut, seperti penyesuaian barisan jamaah atau șaff, penggunaan sutrah, pelaksanaan shalat di atas kendaraan, tanah lapang, perahu dan sebagainya. Diantara implikasi lain yang menjadi sorotan adalah bahwa Muslimah menjadi laik, bahkan dianjurkan, untuk ikut berjamaah di masjid, dengan pertimbangan keramahan, keamanan dan kenyamanan bagi mereka meski dengan syarat tetap memelihara kehormatannya. 


\section{Catatan Akhir:}

${ }^{1}$ Lihat Fadwa el-Guindi, Jilbab antara Kesalehan, Kesopanan dan Perlawanan, terj. Mujiburrohman (Jakarta: Sermbi Ilmu Semesta, 2005).

${ }^{2}$ Fedwa el-Guindi, Jilbab antara Kesalehan, Kesopanan dan Perlawanan terj. (Jakarta: Serambi, 2005), bab V., 97-127.

${ }^{3}$ Amin Abdullah, Urgensi Pendekatan Antropologi dalam Studi Agama dan Studi Islam dalam http://aminabd.wordpress.com/2011/01/14/urgensipendekatan-antropologi-untuk-studi-agama-dan-studi-islam/

${ }^{4}$ Karakter mazhab ini terkait dengan nash-nash syara' yang ada dalam alQur'an dan al-Hadist tidak melakukan penalaran melalui ra'yu yang bersandar pada usaha akal semata. Ahl al-hadits berkembang di Madinah (Hijaz), dengan tokoh utama Malik bin Anas.Lihat Hamid Naseem, Muslim Philosophy Science and Mysticism (India: Sarup and Son, 2001), 31.

${ }_{5}^{5}$ Istilah ahl al-ra'yi digunakan untuk menyebut kelompok pemikir hukum Islam yang memberi porsi akal lebih banyak disbanding dengan pemikir lainnyaAhl al-ra'y berkembang di Kufah (Irak), dengan tokoh utama Abu Hanifah. Bagi Abu Hanifah sumber hukum utama yang dijadikan rujukan ialah al-Qur'an dan Sunnah Rasulullah setelah melalui seleksi yang ketat, dan ketiga fatwa sahabat. Dalam hal ijtihad digunakan ijma', qiyas, istihsan dan 'urf. Lihat Fazlur Rahman, Islamic Methodology in History, (India:Adam Publishers \& Distributors, 1994).

${ }^{6}$ Lihat selengkapnya dalam Nur Syam, Mazhab-mazhab Antropologi (Yogyakarta: 1KIS, 2007), 30-50.

61.

${ }^{7}$ Ed. TO. Ihromi, Pokok-pokok Antropologi Budaya (Jakarta: YOI, 2006),

${ }^{8}$ Muslim bin al-Hajjāj bin Muslim bin Wardi al-Qusyairi an-Naisābūri, Șaḥị̣ Muslim 697, 1632, 1633, Sunan Abū Dawūd 1062, Sunan Nasā'ī 653, Musnad Aḥmad 5934 dalam Maktabah syāmilah.

${ }^{9}$ Muslim bin al-Hajjāj bin Muslim bin Wardi al-Qusyairi an-Naisābūri, Șaḥị̣ Muslim 258, 268, 1158, Sunan Ibn Majāh 955, Șaḥị̣ Ibn Hịbbān 2410, Musnad Aḥmad, 5708, Muḥammad ibn Isḥāq Ibn Khuzaimah Abū Bakar asSulami an-Naisaburi, Șah̄ịh ibn Khuzaimah jilid III, ditahqiq oleh Muștafa alA'zami (Beirut: al-Maktabah al-Islamiy, t.th.), hadis 800 dalam Maktabah syamilah.

${ }^{10}$ Fazlur Rahman, 'concept Sunnah, Ijtihad and Ijma' in the Early Period', Islamic Studies, 1, 1 (1962), 5-21.

${ }^{11}$ Fatima Mernissi, Penafsiran Feminis Tentang Hak-hak Perempuan, dalam Charles Kurrzman (ed.), Wacana Islam Liberal: Pemikiran Islam Kontemporer Tentang Isu-isu Global (Jakarta: Paramadina, 2003), 160.

12 Muhibbin, Hadis dalam Perspektif Kontemporer: Kajian Kritis terhadap Hadis-Hadis Politik, Tesis Pascasarjana IAIN Sunan Kalijaga Yogyakarta Tahun 1994.

13 Muh. Tasrif, Pemikiran Hadis di Indonesia: Wacana tentang Kedudukan dan Pemahaman terhadapnya, Tesis Pascasarjana IAIN Sunan Kalijaga Yogyakarta Tahun 2003. 
${ }^{14}$ Abdul Mustaqim, "Paradigma Interkoneksi dalam Memahami Hadis Nabi (Pendekatan Historis, Sosiologis, dan Antropologis) dalam Jurnal Studi Ilmu-ilmu Al-Qur'an dan Hadis Jurusan Tafsir Hadis UIN Sunan Kalijaga Yogyakarta Volume 9, No. 1 Januari 2008.

15 Suryadi, "Rekonstruksi Metodologis Pemahaman Hadis" dalam Fazlurrahman dkk, Wacana Studi Hadis Kontemporer (Yogyakata: Tiara Wacana Yogya, 2002), 137-150.

${ }^{16}$ Lihat seperti dalam berbagai syarah hadis tentang hadis-hadis persoalan yang dikaji dalam

${ }^{17}$ Sunan Abū Dāwūd 570, Muhammad ibn Ishaq Ibn Khuzaimah Abū Bakr as-Sulami an-Naisābūri, șahịh ibn Khuzaimah, hadis No. 1690, Abī Abdullāh Muḥammad ibn Abdullāh al-Ḥakim an-Naisābūri, al-Mustadrak ala alSahihain, jilid I (Beirut: Dar al-Kutub al-'Ilmiyyah, 1990) hadis No. 713, Aḥmad ibn al-Ḥusain ibn Ali ibn Mūsā Abū Bakar al-Baihaqi, as-Sunan al-Kabīr, jilid III ditahqiq oleh 'Abd al-Qadir Atha' Makkah al-Mukarramah: Maktabah al-Bāz , 1994), hadis no, 5567 dalam Maktabah syāmilah.

${ }^{18}$ Muslim bin al-Hajjaj bin Muslim bin Wardi al-Qusyairi an-Naisaburi, Șaḥ̄h Muslim 132, 1013 dan Sunan Abū Dawūd 678 dalam Maktabah syamilah.

${ }^{19}$ Sulaimān bin al-Asy'as bin Ishāq bin Basyir bin Syidad bin Amar alAzdi as-Sijistāni, Șaḥ̄h Bukhāri 489, 492, Muslim bin al-Ḥajjāj bin Muslim bin Wardi al-Qusyairi an-Naisabūri, Șaḥīh Muslim 261 dan lain-lain dalam Maktabah syamilah.

${ }^{20}$ Muslim bin al-Ḥajjaj bin Muslim bin Wardi al-Qusyairi an-Naisābūri, Șahịḥ Muslim 697, 1632, 1633, Sunan Abū Dawūd 1062, Sunan Nasā’i 653, Musnad Ahmad 5934 dalam Maktabah syamilah.

${ }^{21}$ Muslim bin al-Hajjaj bin Muslim bin Wardi al-Qusyairi an-Naisaburi, Șahịh Muslim 258, 268, 1158, Sunan Ibn Majah 955, Sahih Ibn Hibban 2410, Musnad Ahmad, 5708, Șạ̄īh Ibn Huzaimah 800 dalam Maktabah syamilah.

${ }^{22}$ Sunan Abū Dawūd 1072, Abū 'Abdullāh Muhammad ibn Yazīd ibn Majāh ar-Rabā'iy al-Qazwiniy, Sunan Ibn Majāh 1310 Sunan ad-Dārimi, No. 1665 dalam Maktabah syamilah.

${ }^{23} \mathrm{Abū}$ 'Isa Muḥammad Ibn 'Isā Ibn Ṡawrah Ibn Mūsā Ibn aḍ-Ḍahāk asSulami al-Bugi at-Tirmidzi, Sunan Tirmizi 304 dalam Maktabah syamilah.

${ }^{24} \mathrm{Abū}$ 'Isa Muhammad Ibn 'Isa Ibn S̉awrah Ibn Mūsā Ibn aḍ-Dạāk asSulami al-Bughi at-Tirmidzi, Sunan Tirmizi 317, 318. Sunan Ibn Majāh 745, Aḥmad 12108, dan Sunan Dārimi 1441 dalam Maktabah syamilah.

${ }^{25}$ Muslim bin al-Hajjajj bin Muslim bin Wardi al-Qusyairi an-Naisaburi, Muslim 522, 1193, Aḥmad ibn al-Husain ibn Ali ibn Mūsā Abū Bakar alBaihaqi, as-Sunan al-Kabīr, Sunan Baihaqi, 1062 dalam Maktabah syamilah.

${ }^{26}$ Ahmmad ibn 'Umar al-Hazimi, Syarah al-Qawā'id wa al-Usūl al-Jāmi'ah li asy-Saykh as-Sa'di, www. http://www.alhazme.net, h. 2.

${ }^{27}$ Muh. E. Ayyub, dkk., Manajemen Masjid (Bandung: GIP, 2007), 7-8.

${ }^{28}$ Ahmad Fanani, Arsitektur Masjid (Yogyakarta: Bentang, 2009), 241.

${ }^{29}$ Muslim bin al-Hajjaj bin Muslim bin Wardi al-Qusyairi an-Naisābūri, Ṣahị̣̄ Muslim 697, 1632, 1633, Sunan Abū Dāwūd 1062, Sunan Nasai 653, Musnad Ahmad 5934 . 
${ }^{30}$ Sunan Abū Dāwūd, No. 1072, Abū 'Abdullāh Muḥammad ibn Yazīd ibn Mājah ar-Raba'iy al-Qazwiniy, Sunan Ibn Mājah, No. 1310, Sunan adDarīmi, No. 1665.

${ }^{31}$ Șahịị Bukhāri, No. 666.

${ }^{32}$ Șahị̣̂ Bukhāri, No. 666, 669,

${ }^{33}$ Șahịh Bukhāri, No. 674.

\section{DAFATAR PUSTAKA}

Abū 'Abdullāh Muḥammad ibn 'Abdullāh al-Ḥakim an-Naisābūri, al-Mustadrak 'ala al-ṣahihain, jilid I, Beirut: Dār alKutub al-'Ilmiyyah, 1990.

Ahmad Fanani, Arsitektur Masjid, Yogyakarta: Bentang, 2009.

Aḥmad ibn al-Ḥusain ibn 'Ali ibn Mūsā Abū Bakar al-Baihaqi, alSunan al-Kabīr, Jilid III ditahqiq oleh 'Abd al-Qādir Atha', Makkah al-Mukarramah: Maktabah al-Bāz , 1994.

Aḥmad ibn 'Umar al-Hāzimi, Syarah al-Qawā'id wa al-Ușūl alJāmi'ah li al-Saykh al-Sa'di, www. http://www.alhazme.net,

Amin Abdullah, Urgensi Pendekatan Antropologi dalam Studi Agama dan Studi Islam dalam http://aminabd.wordpress.com/2011/01/14/urgensipendekatan-antropologi-untuk-studi-agama-dan-studiislam/

Ed. TO. Ihromi, Pokok-pokok Antropologi Budaya, Jakarta: YOI, 2006.

Fadwa el-Guindi, Jilbab antara Kesalehan, Kesopanan dan Perlawanan, terj. Mujiburrohman, Jakarta: Sermbi Ilmu Semesta, 2005.

Fazlur Rahman, Islamic Methodology in History, India:Adam Publishers \& Distributors, 1994.

Hamid Naseem, Muslim Philosophy Science and Mysticism, India: Sarup and Son, 2001. 
Mernissi, Fatima. Penafsiran Feminis Tentang Hak-hak

Perempuan, dalam Charles Kurrzman (ed.), Wacana Islam

Liberal: Pemikiran Islam Kontemporer Tentang Isu-isu Global. Jakarta: Paramadina, 2003.

Muh. E. Ayyub, dkk., Manajemen Masjid, Bandung: GIP, 2007.

Muhammad ibn Ishāa Ibn Khuzaimah Abū Bakr as-Sulami alNaisabūri, Șahīh ibn Khuzaimah jilid III, ditahqiq oleh Muștafā al-A'ẓami, Beirut: al-Maktabah al-Islāmiy, t.th..

Muhibbin, Hadis dalam Perspektif Kontemporer: Kajian Kritis terhadap Hadis-Hadis Politik, Tesis Pascasarjana IAIN Sunan Kalijaga Yogyakarta Tahun 1994

Mustaqim, Abdul. "Paradigma Interkoneksi dalam Memahami Hadis Nabi (Pendekatan Historis, Sosiologis, dan Antropologis) dalam Jurnal Studi Ilmu-ilmu Al-Qur'an dan Hadis Jurusan Tafsir Hadis UIN Sunan Kalijaga Yogyakarta Volume 9, No. 1 Januari 2008.

Musnad Ahmad ibn Hanbal. Software Maktabah as-Syāmilah alIșdār al-s̄āni, 2002.

Nur Syam, Mazhab-mazhab Antropologi, Yogyakarta: IKIS, 2007.

Rahman, Fazlur. 'concept Sunnah, Ijtihad and Ijma' in the Early Period', Islamic Studies, 1, 11962.

Șahīh Bukhāri. Software Maktabah as-Syāmilah al-Ișdar al-ṡani, 2002.

Ṣahị̄h Ibn Hibbān. Software Maktabah asy-Syāmilah al-Ișdār als̄āni, 2002.

Șahīh Muslim. Software Maktabah asy-Syāmilah al-Ișdār al-sīani, 2002.

Sunan Abū Dāwūd. Software asy-Syāmilah al-Ișdār al-s̄āni, 2002.

Sunan Ibn Mājah. Software Maktabah as-Syāmilah al-Ișdar al-ṡani, 2002.

Sunan an-Nasā’i. Software Maktabah as-Syāmilah al-Ișdar al-siani, 2002. 
Suryadi, "Rekonstruksi Metodologis Pemahaman Hadis" dalam Fazlurrahman dkk, Wacana Studi Hadis Kontemporer. Yogyakata: Tiara Wacana Yogya, 2002.

Tasrif, Muh. Pemikiran Hadis di Indonesia: Wacana tentang Kedudukan dan Pemahaman terhadapnya, Tesis Pascasarjana IAIN Sunan Kalijaga Yogyakarta Tahun 2003 